By LOUIS SHORES

\title{
Audio-Visual Dimensions for an Academic Library
}

Dr. Shores is dean of the library school, Florida State University, and chairman of the ACRL Audio-Visual Committee.

W

HEN A UNIVERSITY LIBRARIAN and a library school dean pause between meetings at a conference what do they talk about? Usually, of course, about filling that staff vacancy. But almost as frequently these days about audio-visual $(\mathrm{A}-\mathrm{V})$ media.

It is no secret that quite a few librarians of institutions of higher education wish these new-fangled non-book gadgets were somewhere near the bottom of the more unfathomable ocean depths. In the last six months alone I have talked with at least one administrator for every type of academic library represented by our ACRL sections who wished the question of $\mathrm{A}-\mathrm{V}$ media in libraries had never come up. Frankly, they say, in agreement with Joseph Wood Krutch, and many other defenders of books, these newer mass media are enemies of reading, and we wonder if our professional responsibility does not call for all-out war. Certainly, the scholarly university library has little reason to cut into its precious research funds for back volumes of the Berichte der Deutsche Chemische Gesellschaft in order to buy a half dozen questionable motion pictures.

Although this position hardly represents even a considerable minority of academic librarians' thinking it is worth considering as a starting point for an $\mathrm{A}-\mathrm{V}$ decision on any campus. For there is considerable fear today that the printed word as a medium of communication may be on the decline. This concern is found not only in the publishing industry, and among writers, but in the profession of librarianship itself. It has already been most fatally predicted by that Frenchman of letters, Georges Duhamel, who wrote as early as I939:

The decadence of the book, the greatest instrument for the diffusion of knowledge, may be delayed a little longer.... As far as France is concerned the evidence seems to point in one direction.... For the man in the street, the book, defenseless, is henceforward to be supplanted by less laborious methods of information and recreation. ${ }^{1}$

Strangely enough the answer to this sort of pessimism comes from an audio-visualist, possibly the foremost audio-visualist in America, and most certainly from the audiovisualist who is authoritatively quoted in research literature in both the $\mathrm{A}-\mathrm{V}$ and reading fields. In a memorable lecture sponsored by the Library School on the Florida State University campus, Edgar Dale called librarians' attention to the fact that printed books were not always respectably accepted in college libraries. During the I 5th century the Duke of Urbino "had a mind to do what no one had done for a thousand years or more; that is to create the finest library since ancient times." But, adds Vespasiano Da Bisticci, the bookseller,

In this library all the books are superlatively good, and written with the pen, and

1 Duhamel, Georges. In Defense of Lctters. New York, Greystone Press, 1939, p. ix. 
had there been one printed volume it would have been ashamed in such company. ${ }^{2}$

Now, after all, Dr. Dale points out, are not these fearful, 2oth century librarians in danger of evaluating $\mathrm{A}-\mathrm{V}$ media in the same terms as their 15 th century forerunner reflected on the products of the printing press? What is more serious, asks Dr. Dale-are librarians not turning their backs on the real mission of libraries? The librarian, as Dr. Dale sees the problem, must not look upon himself

... merely as an agent for the custody and distribution of printed materials but also as an agency for the custody and distribution of illuminating ideas no matter whether they appear on tape, wax, film, paper, or a television screen. ${ }^{3}$

It is well thus to be recalled to our professional mission. If we are dedicated to the dissemination of good ideas, first, the format of these ideas must be of second importance. Our obligation then becomes clear. As administrators of academic libraries we are responsible for the acquisition and dissemination of these ideas whether they appear in book, map, picture, recording, film, or any one of a dozen or more forms. As a matter of fact, it would be difficult indeed to discover a single academic library in these United States without some nonprint materials.

For example, one chapter in any one of the standard $\mathrm{A}-\mathrm{V}$ textbooks deals with maps and globes. ${ }^{4}$ The fact that a cartographic unit is part of any respectable $A-V$ service argues nothing for removal of all geographic representations from the academic library. Maps have always been an integral part of

${ }^{2}$ The Vespasiano Memoirs (Lives of Illustrious Men of the XVth Century) trans. by William George and Emily Waters. New York, Lincoln MacVeagh, 1926,

p. Io2, I04. ${ }^{3}$ Dale, Edgar, "The Challenge of Audio-Visual Media."'In Shores, Louis, ed., Challenges to Librarianship, Tallahassee, Florida State University, 1953, p. I о I.

4 See for example, Wittich, W. A., and Schuler, C. F. Audio-Visual Materials: Their Nature and Use. New York, Harper, 1953. $564 \mathrm{p}$. college and university collections and even the most conservative university librarian would probably concede that he is already partly in the A-V business.

In addition to cartographic and graphic media however, $\mathrm{A}-\mathrm{V}$ concerns itself with what audio-visualists call museum objects and with local resources. Do not be misled. Both classes of $\mathrm{A}-\mathrm{V}$ are now and have long been an integral part of library collections and services. Our exhibit cases are full of both art and science specimens, some owned outright by the library and others borrowed from instructional departments on the campus for the purpose of cooperative display. And as for local resources which provide the media of communication for field trips and school journeys, libraries have been a far more important accessory in the past than generally has been recognized. Consider for example the variety of local indexes developed, not only by public libraries, but by academic libraries, to various cultural, social, educational, and other agencies, to industrial and commercial activities in the town and county, to the faculty researches and interests and specialities, and hobbies, and yes, even to the natural resources of the campus environment. Without these library operations the field trips of $\mathrm{A}-\mathrm{V}$ would be less meaningful if not more difficult.

And so we come to the more frightening categories of $\mathrm{A}-\mathrm{V}$ materials. To the audiovisualist the "flat picture" is a must among media. Do not let the word "flat" frighten you. Library vertical files are full of pictures. Among library reference books there are even a few indexes to these same pictures. Even the conservative librarian who does not keep a picture file must admit he is not representative and that a great number of his colleagues have been $\mathrm{A}-\mathrm{V}$ for a long time.

But what about phono-records, as the 
Saturday Review now calls them. It does not take a very old librarian to recall the Carnegie collections of fine recordings presented to scores of colleges in the United States. Many of the college browsing rooms still maintain record libraries of good music, drama, elocution, and language. Other libraries have cooperated with foreign language departments to promote speaking as well as reading and writing in a foreign tongue. And in a few instances research on the campus has been assisted by the library's recording and preserving men's dialects and animals' sounds. Perhaps here the conservative university librarian would agree the academic librarian has been and of right should be A-V.

This brings us to the film and projected materials. Certainly there is no argument about the microfilm now. To us the machine we use with it is a reader; to the audio-visualist it is possibly just another projector. At the very least it puts both librarian and audio-visualist in the same camp as far as using another format-a film format for the dissemination of ideas. Probably the one medium on which the librarian might balk is the $16 \mathrm{~mm}$ motion picture. But an increasing number of all kinds of libraries are renting these films for classroom use and for library study, and in some instances purchasing them.

It can be seen, therefore, class by class, that $A-V$ media are no strangers to libraries. They are potentially other formats for ideas. Basically, they lend themselves to the library processes of acquisition, preparation, interpretation, and dissemination. Physically and financially they confront librarianship with certain peculiar problems, but with problems no more peculiar than the various classes of media already professionalized in our library literature.

Let's examine some of these problems. In the first place the academic library should look toward the centralization of responsibility for A-V media on campus. This need not mean centralization of housing, but it certainly should mean centralized inventory. Along with central inventory at least coordinated acquisition should be sought. The argument is the same as that for centralization of print material acquired by the institution of higher education through its library.

In the second place, as soon as possible, the academic library should provide personnel qualified to serve the campus in as many of the A-V media as possible. To begin with, the smaller library may assign part time to the best qualified staff member. As soon as possible however, the library should plan to employ a librarian trained in the $\mathrm{A}-\mathrm{V}$ field. Increasingly our library schools are incorporating $A-V$ courses and units in the basic professional curriculum, equipping a new generation of librarians for $A-V$ service.

In the third place the agencies and departments of instruction most audio-visually inclined should be enlisted in developing a plan for the campus. On most campuses the school or department of education and the extension agency will be in the $A-V$ vanguard. But let not the traditional scholar take comfort in that. The colleges of arts and sciences are by far the heaviest users of these A-V media: 1) $16 \mathrm{~mm}$ film, 2) glass slides, 3) maps, 4) opaque objects. Departments in the general college, in the sciences, in the fine arts, among others, should therefore be approached early in any plan to coordinate $A-V$ services for the campus. A very good beginning is the appointment of a representative faculty committee on $A-V$ services to plan with the librarian. This committee may be either a sub-committee of the library committee or a separate committee.

In the very beginning about eight basic 
aspects of $A-V$ services as aids to campus instruction and research should come under the survey by the library and its $\mathrm{A}-\mathrm{V}$ committee. The cartographic unit in embryo will already be functioning in most academic libraries. In cooperation with the history and geography departments and with other heavy users the available maps, globes, atlases and geographic services on the campus will be canvassed. Augmented indexing and cataloging will be undertaken where necessary and additional accessions recommended to support the campus' total holdings, now inventoried in the library. If production of special or local maps is called for it will probably be decided to do the work in the geography department or in the library.

Next the graphics unit will come up for consideration. Civilian institutions are still lagging behind in instructional use of various charts, graphs, demonstrations and other graphics used in military instruction. The average library, however, produces considerable bulletin board material and reproduces through mimeograph, lithograph or photostat both research and instructional materials that might be filed for future reference. This the library frequently does for its own graphics. But on the campus various other graphics are being produced that are either dead stored in some department office or destroyed, though their value is not necessarily limited to a single use. If the library could at least start a campus pool of instructional graphics organized for subject use another valuable contribution to the dissemination of ideas might well be made. Whether the library should undertake production of graphics material for various departments of the campus will need particular study in cooperation with the fine and industrial arts departments.

The third inventory will involve museum objects. Many of these are already in the library. Others are in various art and science departments. If the campus has a museum a huge collection will be there. It is important to emphasize that the campus library does not have to become a museum, even though the British Museum is one of the greatest libraries in the world. But the library has an obligation in keeping with its mission to disseminate ideas in whatever format they may be found in and on the campus. And in keeping with that mission the library should endeavor without duplication to organize for bibliographic dissemination the museum objects that will contribute to more effective instruction and research carried on by the institution. In this connection and in relation to other classes of library materials the library should have available opaque projectors for departmental and library use.

A fourth inventory of local resources will consist basically of a review of the indexing, abstracting, and other bibliographic services now part of the library. Whatever human and environmental resources, available within a convenient radius, are not readily known should be cataloged and disseminated to the part of the campus concerned. Certainly, faculty planning field trips and expeditions should be expected to utilize what the library can contribute.

A fifth canvass will involve pictorial illustrations of all kinds-separate, in books and periodicals, in the art department, and elsewhere on campus. There is nothing new here for libraries. Many remarkable collections can be found in libraries now. Libraries without such collections will find untapped sources among citizens, alumni, friends.

A sixth investigation will involve recordings, both disc and tape. Increasingly the library must build its collections to serve the many departments that now use sound in instruction and research. The creation 
of listening posts in the reading rooms as well as listening rooms acoustically treated deserve campus librarians' consideration. The listening post in the reading room may have as many as six sets of earphones, thus providing the language, or music, or speech student with an auditory accompaniment to his reading effort. Tapes of significant radio programs may be the most valuable of all books for particular instructional situations. This means that the library must include tape recorders in its equipment as well as playbacks for discs.

The seventh consideration is films, and this is the one the worried librarian looks upon as the $A-V$ problem. Microtexts and the readers needed with them are already an integral part of the academic library. But the $16 \mathrm{~mm}$ motion picture is not. What is more the investment required for even a small collection of films to say nothing of the projector is disproportionate to the budget of the average small college library. There are two solutions to this budget problem. Film renting from the state library of films or from out-of-state film libraries is within the range of most libraries. Cooperative buying with other college libraries and the organization of film circuits provide an opportunity for each participating library to disseminate many highly effective instructional films to the departments using them. It must also be remembered that many of the best films are free. The steadily rising quality of the sponsored film is making it an ever more effective medium for college instruction.

Finally, the place of radio and television in the library must be thoroughly con- sidered. Libraries are already indexing and disseminating information about good programs. Some libraries tape them. But the real library opportunity is in shaping television programs yet to come. In this connection I cannot resist quoting Edgar Dale's remarks to librarians:

I should like to propose a slogan for libraries that may suggest what they can do: "Your library has the best ideas in the world." Through television you will have an opportunity to show ... just what your resources are ... books, reference materials, encyclopedias ... in short television gives you a showcase in every television home in your community. You can display your wares in their living room. ${ }^{5}$

These are some of the audio-visual dimensions of an academic library. Despite the general terms in which they have been presented these dimensions are not only academic but applied. In at least one case when the library school dean advises the university librarian to go $\mathrm{A}-\mathrm{V}$ there is a tangible basis for the advice. On the campus of Florida State University there is a centralized $\mathrm{A}-\mathrm{V}$ service, administered by the Library School in cooperation with the University Library and the various schools and colleges on the campus. All eight of the aspects are represented. Various degrees of centralization have been accomplished. But the growing concept of unity of library media is an unquestioned asset to both instruction and research. By means of all of the formats the world's best ideas are increasingly permeating the process of higher education.

5 Dale, op. cit., p. 104. 